\title{
THE OSMOTIC PRESSURE OF PROTEINS IN WHOLE SERUM ${ }^{1}$
}

\author{
By CARL H. WIES 2 and JOHN P. PETERS \\ (From the Department of Internal Medicine, Yale University, School of Medicine, New Haven)
}

(Received for publication September 4, 1936)

A study has been made of the colloidal osmotic pressure of human sera and pathological accumulation of fluids in an effort to gain information concerning the relations of semipermeable membranes and biological colloids and particularly to determine in serum the osmotic effects of the important colloids, albumin and globulin.

\section{METHOD}

For the sake of economy of material and technical simplicity an osmometer with a flat membrane was selected. For membranes, collodion, prepared according to the method of Pierce (1) was used at first, since the results seemed to be uniform and reproducible. However, this was soon abandoned for cellophane, with which all the measurements here presented were made. This material was used by Govaerts (2) for his original experiments in 1923 and has been shown by Turner (3) to be well adapted to measurements of colloid osmotic pressure. It can be secured in a highly uniform quality, and a single sheet, a meter square, is sufficient for a great number of measurements. It has another property which led to its substitution for collodion. Hitchcock (4) has shown that collodion films absorb protein in definite relation to their permeability. Collodion may also absorb other constituents from solutions. It has been found that $\mathrm{HCl}$ is formed when collodion is shaken with solutions of $\mathrm{KCl}$. Smith and Sternberger (5) found that as much as 12 per cent of the calcium of serum was adsorbed by collodion sacs in ultrafiltration experiments. It was demonstrated by preliminary experiments that cellophane does not adsorb protein from serum or diluted serum, a fact which Hitchcock (6) had established for other proteins. The effect of adsorption of protein by the membrane on measurements of osmotic pressure is not known because the osmotic activity of the adsorbed protein has not been determined. Nevertheless, the use of a membrane which does not adsorb protein would seem to be preferable if only because it eliminates one unknown factor. Experiments have not been made to ascertain whether cellophane, like collodion, adsorbs other ions or forms $\mathrm{HCl}$ from $\mathrm{KCl}$.

The osmometer finally adopted is illustrated in Figure 1. It is not strictly original in design, but a modification of those described by Govaerts (2), Krogh and Nakazawa (7), Hill (8) and Moore and Roaf (9). It is so

\footnotetext{
1 Part of the expense of this investigation was met by a grant from the Ella Sachs Plotz Fund.

2 Alexander Brown Coxe Fellow in Medicine.
}

constructed that the fluid under examination comes into contact only with glass, rubber and the membrane. The metal clamping pieces are entirely external, to eliminate electrical charges on metallic ions, which, as Cox and Hyde (10) have shown, may have a definite effect in ultrafiltration.

The osmometer was at first set up in the usual manner, the membrane supported by a hard rubber disc perforated with many fine holes. Against the lower surface of the perforated disc was placed a piece of blotting paper saturated with normal saline. This was separated from the salt solution of the constant temperature water bath by an air bubble. Owing to capillarity set up by the moisture in the holes of the perforated disc and by the surface film of the air bubble, erratic results were obtained. When the manometers were set up with physiological salt solution in the cell and on the blotting paper the pressure on the balancing manometer plus the column of fluid in the capillary tube above the surface of the bath did not equal, as it should, the sum of the rise in the capillary tube plus the height of the air bubble below the manometer. However, when the supporting disc and the air bubble were removed, i.e. when saline was in contact with both sides of the membrane, more nearly theoretical results were obtained. Therefore, the supporting disc was discarded and the manometer set up as it is depicted in the figure, with no air bubble and with blotting paper alone to support the membrane.

The cellophane is first thoroughly washed in saline to swell it and to remove glycerol. It is then cut into discs, each of which is floated in saline between a disc of white blotting paper and a thin rubber washer of the same size. When they are required for use the membranes with washers and blotters are pressed gently between pieces of dry filter paper to remove excess saline, after which they are placed in the osmometer, where they are held by firm pressure from the bottom metal cap. Just enough fluid to be examined is now introduced through the top so that it will overflow when the capillary tube is in place, with care to exclude the formation of bubbles. The capillary tube is added, the top gland nut screwed down, and the capillary tube moved until the meniscus stands about $70 \mathrm{~mm}$. above the body of the instrument. The osmometer is placed in the water bath and connected by heavy-walled rubber tubing to the balancing column of air and water. Low vapor pressure stopcock grease is used to seal joints. The air bubble trapped under the blotting paper is carefully removed.

The meniscus is observed by means of a thermometer reader which is placed on the tube at the original level of the meniscus. Sufficient counter pressure is applied 


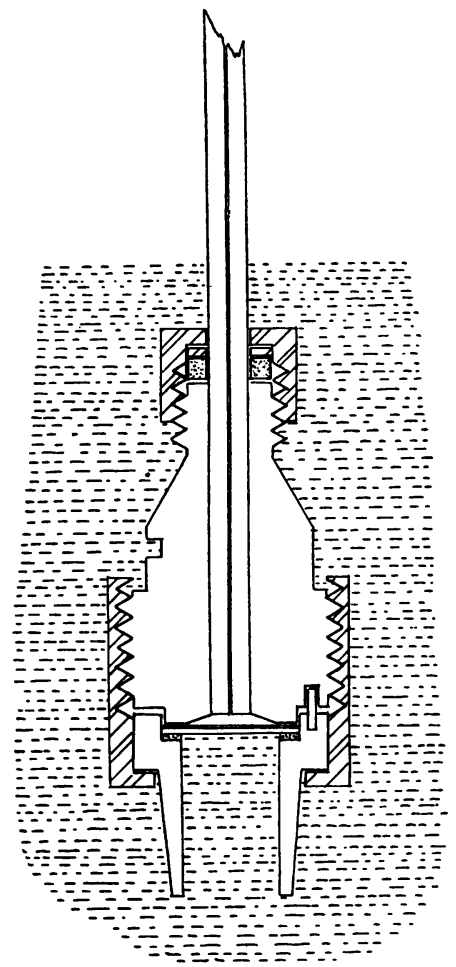

$b$

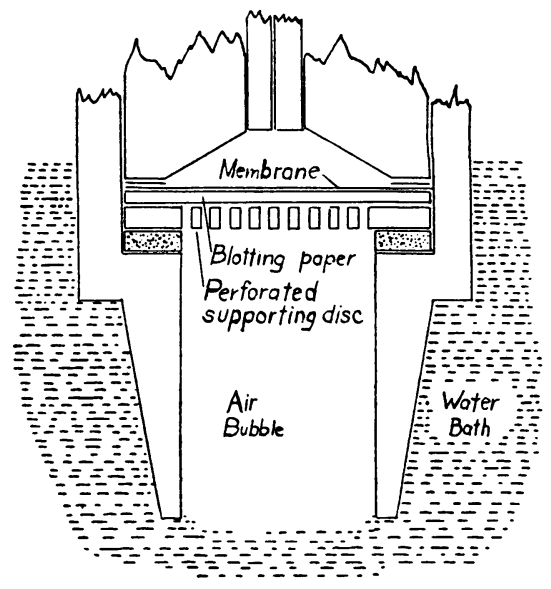

a

Fig. 1. Detail Osmometer: $(a)$ as it was First Set Up; $(b)$ as it was Finally Used.

with a leveling bulb so that the volume of fluid in the osmometer does not change. Frequent adjustments are necessary in the first several hours. The final reading is made at the end of 24 hours. The balancing pressure is measured on a more conveniently located scale against which the leveling bulb is moved.

The temperature of the bath was kept at $20^{\circ} \mathrm{C} . \pm 0.10$ by means of a toluene-mercury thermoregulator in conjunction with a relay and heating coil, circulation being maintained by a jet of air. Since $0.2 \mathrm{~mm}$. capillary tubing was employed, the volume of serum in the chamber was large in proportion to that in the tubing. Therefore, changes in pressure manifested themselves quickly in movements of the meniscus. The latter was observed with an ordinary thermometer reader, which gave results as precise as the error in the entire method justified. Readings were made at the end of 24 hours and verified after a further interval of 2 hours. If tapping the tube changed the level of the meniscus, another reading was made. It was found that after 24 hours, readings remained constant. These observations were made before the publication of Yanagi (11) who found an apparent change in the colloid osmotic pressure of hypoproteinemic sera after the fifth or sixth hour. This point was not examined specifically. However, there is no evidence, as will be shown later, that the colloid osmotic pressure of sera with low proteins is lower than theoretical considerations demand. Repeated measurements of the capil- larity of the glass tubes of the osmometers averaged 48 $\mathrm{mm}$. with a variety of sera. Because sufficient material was not always available to permit separate determinations of this correction on each sample of serum, a standard correction of $48 \mathrm{~mm}$. was used. All determinations were made in duplicate, some in triplicate.

Dilutions of sera were made by adding to 1 or more whole cc. of serum the desired amount of physiological saline by drops from a pipette that yielded 30 drops per cc. Sera were not analyzed for protein after dilution.

Serum proteins were determined by Howe's (12) method.

Blood was withdrawn without stasis, and serum was removed with anaerobic precautions (13) to prevent exchanges of water between serum and cells.

In 35 instances, measurements were made on native serum and on the same serum diluted with saline. In 75 of these experiments 2 dilutions were examined, in the other 18 only one. These dilution experiments served a double purpose: they permitted an investigation of the effects of dilution on osmotic pressure and at the same time provided large families of sera containing equal concentrations of either albumin or globulin.

It is difficult with serum to ascertain the actual error of the method because serum cannot be stored for any considerable period and because sera with identical concentrations of protein can not be found. An ampoule of acacia (Lilly's), opened with aseptic precautions, after 
dilution with sterile water, was subdivided into $10 \mathrm{cc}$. lots, each of which was placed in a sterile sealed ampoule. This provided a stock of constant material, 6 per cent acacia in normal saline, that could be used at intervals to check the method. The average reading from 18 different observations on this material was $252 \mathrm{~mm} . \mathrm{H}_{2} \mathrm{O}$, with a standard deviation of 7 and a maximum deviation of $11 \mathrm{~mm}$. These readings agree fairly closely with measurements made by $\mathrm{Dr}$. Abby $\mathrm{H}$. Turner on the same material.

TABLE I

Differences between duplicate measurements of colloid osmotic pressure of serum

\begin{tabular}{|c|c|c|c|c|}
\hline$\underset{\pi}{\text { Range of }}$ & $\begin{array}{c}\text { Number } \\
\text { of } \\
\text { obser- } \\
\text { vations }\end{array}$ & $\begin{array}{c}\text { Average } \\
\text { difference }\end{array}$ & $\begin{array}{l}\text { Standard } \\
\text { deviation }\end{array}$ & $\begin{array}{c}\text { Average } \\
\text { difference }\end{array}$ \\
\hline $\begin{array}{r}\quad m m . \mathrm{H}_{2} \mathrm{O} \\
\quad<50 \ldots \ldots \\
50 \text { to } 100 \ldots \ldots \\
100 \text { to } 150 \ldots \ldots \\
150 \text { to } 200 \ldots \ldots \\
200 \text { to } 250 \ldots \ldots \\
250 \text { to } 300 \ldots \ldots \\
300 \text { to } 350 \ldots \ldots \\
>350 \ldots \ldots\end{array}$ & $\begin{array}{r}5 \\
16 \\
34 \\
19 \\
33 \\
24 \\
14 \\
6\end{array}$ & $\begin{array}{c}m m . \mathrm{H}_{2} \mathrm{O} \\
10 \\
6 \\
8 \\
8 \\
11 \\
10 \\
16 \\
8\end{array}$ & $\begin{array}{c}m m . \mathrm{H}_{2} \mathrm{O} \\
11.4 \\
7.8 \\
10.4 \\
9.5 \\
14.7 \\
12.5 \\
19.6 \\
11.7\end{array}$ & $\begin{array}{c}\text { per cent } \\
22.5 \\
6.8 \\
6.4 \\
4.6 \\
4.7 \\
3.6 \\
5.2 \\
2.1\end{array}$ \\
\hline Total & 151 & 7.5 & 12.5 & 7 \\
\hline
\end{tabular}

Table I presents statistically the differences between duplicate or triplicate analyses of sera. The errors are approximately the same at all levels of osmotic pressure and therefore relatively larger when the osmotic pressure is small. The probable error can be taken as about 10 $\mathrm{mm}$. of water. This is undesirably large, but seems from experience close to the minimum that can be achieved by clinically practicable techniques. It is evident that measurements on serum are far less reproducible than similar measurements on standard solutions of acacia. This may be partly referable to the fact that the proteins of serum are subject to bacterial and enzymatic decomposition against which no precautions other than chemical cleanliness were taken.

\section{ANALYSIS OF RESULTS}

The experimental data are presented in Table II. In all, there were 173 examinations of 121 sera from 103 subjects, normal adults and patients with a great variety of diseases. The first 51 determinations represent the 17 experiments in which the osmotic pressure was measured in native serum and two dilutions; the next 36 , the 18 experiments in which measurements were made in one dilution; the remainder record single observations. In some instances the same subject was examined on more than one occasion. In the statistical analyses described below the third observation (second dilution) on the serum of Subject 12
TABLE II

Serum protein and colloid osmotic pressure (Bracketed data represent dilutions from single samples of serum)

\begin{tabular}{|c|c|c|c|}
\hline Subject & Albumin & Globulin & $\begin{array}{l}\text { Osmotic } \\
\text { pressure }\end{array}$ \\
\hline \multirow{4}{*}{1} & per cent & per cent & mm. $\mathrm{H}_{2} \mathrm{O}$ \\
\hline & $\int \begin{array}{l}4.00 \\
300\end{array}$ & $\begin{array}{l}-\quad 1.54 \\
\quad 116\end{array}$ & 230 \\
\hline & $\left\{\begin{array}{l}3.00 \\
2.00\end{array}\right.$ & $\begin{array}{l}1.16 \\
0.77\end{array}$ & $\begin{array}{r}153 \\
91\end{array}$ \\
\hline & 4.00 & 2.58 & 230 \\
\hline \multirow[t]{2}{*}{2} & 3.00 & 1.93 & 148 \\
\hline & 2.00 & 1.29 & 93 \\
\hline \multirow{3}{*}{3} & 3.00 & $\begin{array}{l}2.00 \\
1.95\end{array}$ & $\begin{array}{l}207 \\
101\end{array}$ \\
\hline & 2.00 & 1.30 & $\begin{array}{l}191 \\
122\end{array}$ \\
\hline & 2.44 & 2.97 & 166 \\
\hline \multirow[t]{2}{*}{4} & 1.64 & 2.00 & 114 \\
\hline & $\begin{array}{l}0.82 \\
3.00\end{array}$ & $\begin{array}{l}1.00 \\
1.52\end{array}$ & $\begin{array}{l}100 \\
169\end{array}$ \\
\hline \multirow[t]{3}{*}{5} & 2.00 & 1.01 & 109 \\
\hline & 1.00 & 0.51 & 88 \\
\hline & 3.00 & 1.98 & 204 \\
\hline \multirow{2}{*}{6} & 2.00 & 1.32 & 157 \\
\hline & $\begin{array}{l}1.00 \\
5.00\end{array}$ & $\begin{array}{l}0.06 \\
2.12\end{array}$ & $\begin{array}{r}94 \\
303\end{array}$ \\
\hline \multirow[t]{2}{*}{7} & 4.00 & 1.70 & 217 \\
\hline & $\begin{array}{l}3.00 \\
1.58\end{array}$ & $\begin{array}{l}1.27 \\
2.00\end{array}$ & $\begin{array}{l}147 \\
141\end{array}$ \\
\hline \multirow[t]{3}{*}{8} & 1.00 & 1.27 & 73 \\
\hline & 0.79 & 1.00 & 81 \\
\hline & 4.00 & 2.49 & 220 \\
\hline \multirow{2}{*}{9} & 3.00 & 1.87 & 135 \\
\hline & $\begin{array}{l}2.00 \\
4.31\end{array}$ & $\begin{array}{l}1.25 \\
2.00\end{array}$ & $\begin{array}{l}112 \\
269\end{array}$ \\
\hline \multirow[t]{3}{*}{10} & 3.00 & 1.40 & 187 \\
\hline & 2.00 & 0.94 & 127 \\
\hline & 3.00 & 2.95 & 201 \\
\hline \multirow[t]{2}{*}{11} & 2.00 & 1.96 & 134 \\
\hline & $\begin{array}{l}1.00 \\
3.28\end{array}$ & $\begin{array}{l}0.98 \\
2.35\end{array}$ & $\begin{array}{r}81 \\
250\end{array}$ \\
\hline \multirow[t]{3}{*}{12} & 0.91 & 0.29 & 72 \\
\hline & 0.89 & 0.04 & 69 \\
\hline & 4.00 & 2.25 & 277 \\
\hline \multirow[t]{2}{*}{13} & 3.55 & 2.00 & 214 \\
\hline & $\begin{array}{l}1.78 \\
3.00\end{array}$ & $\begin{array}{l}1.00 \\
3.07\end{array}$ & $\begin{array}{l}101 \\
205\end{array}$ \\
\hline \multirow[t]{3}{*}{14} & 2.00 & 2.05 & 115 \\
\hline & 1.00 & 1.02 & 48 \\
\hline & 4.61 & 5.10 & 380 \\
\hline \multirow[t]{2}{*}{15} & 4.00 & 4.33 & 334 \\
\hline & 3.00 & $\begin{array}{l}3.32 \\
5.45\end{array}$ & $\begin{array}{l}262 \\
330\end{array}$ \\
\hline \multirow[t]{5}{*}{16} & 3.00 & $\begin{array}{l}5.45 \\
4.08\end{array}$ & 191 \\
\hline & 2.00 & 2.73 & 153 \\
\hline & 3.00 & 3.47 & 205 \\
\hline & 2.00 & 2.31 & 109 \\
\hline & 1.00 & 1.16 & 65 \\
\hline 17 & 3.91 & 2.55 & 235 \\
\hline & 2.09 & 1.12 & $\begin{array}{r}139 \\
96\end{array}$ \\
\hline 18 & $\begin{array}{l}1.86 \\
1.00\end{array}$ & $\begin{array}{l}2.53 \\
1.36\end{array}$ & $\begin{array}{l}90 \\
35\end{array}$ \\
\hline & 4.49 & 2.36 & 291 \\
\hline 19 & 1.00 & 0.53 & 45 \\
\hline 20 & 4.15 & 2.05 & 232 \\
\hline & 2.07 & $\begin{array}{l}1.02 \\
1.95\end{array}$ & $\begin{array}{l}124 \\
234\end{array}$ \\
\hline 21 & $\begin{array}{l}4.25 \\
2.12\end{array}$ & $\begin{array}{l}1.95 \\
0.98\end{array}$ & $\begin{array}{l}234 \\
128\end{array}$ \\
\hline & 3.17 & 4.19 & 214 \\
\hline 22 & 0.99 & 1.06 & 80 \\
\hline 23 & 4.27 & 2.00 & 221 \\
\hline & 2.14 & 1.00 & 42 \\
\hline
\end{tabular}


TABLE II-Continued

\begin{tabular}{|c|c|c|c|}
\hline Subject & Albumin & Globulin & $\begin{array}{l}\text { Osmotic } \\
\text { pressure }\end{array}$ \\
\hline & per cent & per cent & $m m . \mathrm{H}_{2} \mathrm{O}$ \\
\hline 24 & $\left\{\begin{array}{l}3.00 \\
2.00\end{array}\right.$ & $\begin{array}{l}1.88 \\
1.25\end{array}$ & $\begin{array}{l}171 \\
119\end{array}$ \\
\hline 25 & $\left\{\begin{array}{l}3.37 \\
1.61\end{array}\right.$ & $\begin{array}{l}2.07 \\
1.00\end{array}$ & $\begin{array}{l}256 \\
106\end{array}$ \\
\hline 26 & $\left\{\begin{array}{l}2.05 \\
1.70\end{array}\right.$ & $\begin{array}{l}2.37 \\
2.00\end{array}$ & $\begin{array}{r}120 \\
91\end{array}$ \\
\hline & 4.00 & 2.38 & $\begin{array}{r}91 \\
255\end{array}$ \\
\hline 27 & 2.00 & 1.19 & 169 \\
\hline 28 & $\left\{\begin{array}{l}3.00 \\
2.00\end{array}\right.$ & $\begin{array}{l}2.89 \\
1.93\end{array}$ & $\begin{array}{l}192 \\
113\end{array}$ \\
\hline 29 & 4.05 & 3.52 & 326 \\
\hline 29 & 2.00 & 1.74 & 140 \\
\hline 30 & 3.97 & 2.00 & 273 \\
\hline & $\begin{array}{l}1.89 \\
3.35\end{array}$ & $\begin{array}{l}1.00 \\
3.05\end{array}$ & $\begin{array}{l}109 \\
219\end{array}$ \\
\hline 31 & 2.20 & 2.00 & 119 \\
\hline 32 & $\left\{\begin{array}{l}3.97 \\
1.99\end{array}\right.$ & $\begin{array}{l}2.07 \\
1.04\end{array}$ & $\begin{array}{l}219 \\
107\end{array}$ \\
\hline 33 & 3.01 & 1.46 & 216 \\
\hline 30 & 2.00 & 0.97 & 122 \\
\hline 14 & 2.70 & 4.00 & 191 \\
\hline 17 & $\begin{array}{l}1.36 \\
3.52\end{array}$ & $\begin{array}{l}2.00 \\
1.99\end{array}$ & $\begin{array}{r}82 \\
221\end{array}$ \\
\hline & 3.73 & 2.37 & 261 \\
\hline $\begin{array}{l}18 \\
19\end{array}$ & 1.55 & 2.34 & 91 \\
\hline & $\begin{array}{l}4.35 \\
4.39\end{array}$ & 2.30 & 307 \\
\hline & 4.72 & 2.60 & 332 \\
\hline 22 & 2.90 & 3.60 & 228 \\
\hline 23 & 3.70 & 2.00 & 172 \\
\hline 33 & 2.45 & 1.06 & 206 \\
\hline 34 & 4.12 & 2.50 & 223 \\
\hline 35 & 4.33 & 1.64 & 303 \\
\hline 36 & 3.60 & 2.82 & 279 \\
\hline 37 & 4.48 & 2.54 & 260 \\
\hline 38 & 4.97 & 2.10 & 309 \\
\hline 39 & 4.11 & 2.08 & 258 \\
\hline 40 & 3.40 & 3.22 & 237 \\
\hline 41 & 5.47 & 2.57 & 404 \\
\hline 42 & 4.49 & 2.37 & 284 \\
\hline 43 & $\begin{array}{l}4.45 \\
7.70\end{array}$ & 2.28 & 253 \\
\hline $\begin{array}{l}44 \\
45\end{array}$ & $\begin{array}{l}2.79 \\
4.18\end{array}$ & $\begin{array}{l}2.57 \\
2.00\end{array}$ & $\begin{array}{l}171 \\
283\end{array}$ \\
\hline & $\begin{array}{l}4.10 \\
4.24\end{array}$ & $\begin{array}{l}2.00 \\
2.35\end{array}$ & 247 \\
\hline & 4.48 & 2.30 & 307 \\
\hline 46 & 4.00 & 2.00 & 191 \\
\hline 47 & 3.00 & 1.22 & 139 \\
\hline 48 & 4.53 & 1.96 & 245 \\
\hline 49 & 4.20 & 2.96 & 300 \\
\hline 50 & 3.21 & 3.36 & 225 \\
\hline 51 & 4.42 & 2.12 & 324 \\
\hline & $\begin{array}{l}4.88 \\
2.57\end{array}$ & $\begin{array}{l}2.43 \\
2.23\end{array}$ & $\begin{array}{l}355 \\
114\end{array}$ \\
\hline 53 & 4.28 & 3.92 & 258 \\
\hline 54 & 4.70 & 2.29 & 253 \\
\hline 55 & 2.00 & 2.06 & 129 \\
\hline $\begin{array}{l}56 \\
57\end{array}$ & 3.94 & 3.13 & 285 \\
\hline $\begin{array}{l}57 \\
58\end{array}$ & $\begin{array}{l}4.11 \\
3.84\end{array}$ & $\begin{array}{l}3.50 \\
3.02\end{array}$ & $\begin{array}{l}265 \\
261\end{array}$ \\
\hline $\begin{array}{l}58 \\
59\end{array}$ & $\begin{array}{l}3.84 \\
3.66\end{array}$ & $\begin{array}{l}3.02 \\
2.55\end{array}$ & $\begin{array}{l}201 \\
269\end{array}$ \\
\hline $\begin{array}{l}59 \\
60\end{array}$ & $\begin{array}{l}0.00 \\
1.61\end{array}$ & $\begin{array}{l}2.53 \\
1.00\end{array}$ & $\begin{array}{l}209 \\
130\end{array}$ \\
\hline 61 & 3.22 & 2.00 & 204 \\
\hline 62 & 3.38 & 2.09 & 198 \\
\hline 63 & 3.00 & 1.62 & 171 \\
\hline 64 & 5.09 & 2.36 & 375 \\
\hline 65 & 3.84 & 1.92 & 261 \\
\hline
\end{tabular}

TABLE II-Continued

\begin{tabular}{|c|c|c|c|}
\hline Subject & Albumin & Globulin & $\begin{array}{l}\text { Osmotic } \\
\text { pressure }\end{array}$ \\
\hline $\begin{array}{r}66 \\
67 \\
68 \\
69 \\
70 \\
71 \\
72 \\
74 \\
75 \\
76 \\
\\
77 \\
78 \\
79 \\
80 \\
81 \\
82 \\
83 \\
\\
84 \\
85 \\
86 \\
87 \\
88 \\
89 \\
90 \\
91 \\
92 \\
93 \\
94 \\
95 \\
96 \\
97 \\
98 \\
99 \\
100 \\
101 \\
102 \\
103\end{array}$ & 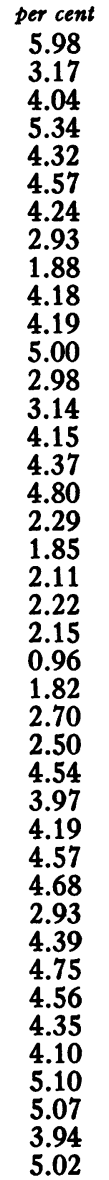 & 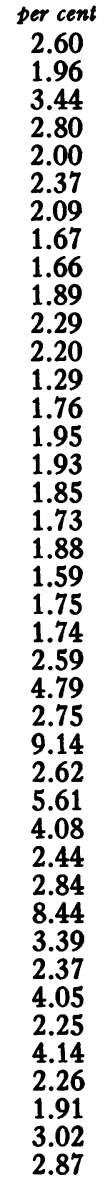 & 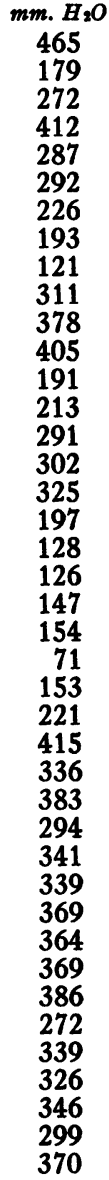 \\
\hline
\end{tabular}

was omitted, because the partition of protein is probably erroneous and the concentration of globulin absurdly low.

The following symbols will be used throughout the discussion of the data:

$P, A$, and $G$ represent grams of protein, albumin and globulin, respectively, in $100 \mathrm{cc}$. of serum.

$p, a$, and $g$ represent the osmotic pressures of 1 gram of protein, albumin and globulin, respectively, in $100 \mathrm{cc}$. of serum.

$\pi=$ the colloid osmotic pressure of serum in mm. $\mathrm{H}_{2} \mathrm{O}$.

$W=$ the grams of water in $100 \mathrm{cc}$. of serum.

It has been repeatedly demonstrated that the relation of $\mathrm{P}$ to $\pi$ is curvilinear, that the apparent 
osmotic pressure per gram per cent of protein increases with the concentration of protein $(7,14$, $15,16,17,18,19,20,21)$. There is no agreement, however, concerning the nature or magnitude of the curvature. Part of the confusion results from the failure to differentiate the results of statistical treatment of clinical data from the results of dilution and concentration experiments. The former may be dismissed shortly. The curved relation of $P$ to $\pi$ in raw material arises chiefly from the fact that low protein in serum is almost always and entirely referable to deficiency of albumin, osmotically the more active of the protein fractions. With the exception of Grönwall (21), those who have centered their attention upon dilution and concentration experiments have found relatively slight curvatures. Even Grönwall finds the ratio $\pi / \mathrm{P}$ reasonably constant within limits of protein concentration found in sera of normal subjects or patients.

Theoretically, the osmotic pressure of the proteins as actually measured includes, in serum, in addition to the true osmotic pressure of the proteins, an increment contributed by the Gibbs-Donnan effect. Because of their large molecular size a small correction must also be made for the volume of the proteins, since osmolar concentration is properly expressed in terms of mols of solute per weight of water in any mixture. The curvature from this source should, if there is no " bound" or non-solvent water, be small.

It was hoped that the dilution experiments would provide a basis for evaluation of the curvature. In the three-point experiments there is, as theory demands, a perceptible tendency for $\pi / \mathrm{P}$ to diminish with $\mathrm{P}$. There are, however, distinct exceptions to the rule, particularly among sera with originally low concentrations of protein. It has already been mentioned that analytical errors are greater when protein is low. In the two-point experiments there is a similar tendency for $\pi / \mathrm{P}$ to vary with $P$. In both series, the variation is so small and so variable that the curvature which it represents cannot be evaluated. It is evident that it is small, but significant. It is quite probable, judging from the investigations of Adair and Robinson (19), Mayrs (15) and others, that even if the analytical methods were greatly refined, a certain amount of variability would persist. The curvature is appreciably diminished, but not abolished when the concentration of protein is corrected from grams per $100 \mathrm{cc}$. to grams per kilo of water by the aid of the equation, $W=98.40-0.718 \mathrm{P}$, developed by Eisenman, Mackenzie and Peters (22).

TABLE III

Relation of concentration of total protein, $P$, to osmotic pressure $\pi$

\begin{tabular}{|c|c|c|c|c|c|}
\hline $\begin{array}{l}\text { Number of } \\
\text { observations }\end{array}$ & $\underset{\mathbf{P}}{\text { Range of }}$ & $\underset{\mathbf{P}}{\text { Average }}$ & $\underset{\pi}{\text { Average }}$ & $\pi / P$ & A/G \\
\hline $\begin{array}{c}20 \\
26 \\
24 \\
21 \\
48 \\
21 \\
13 \\
\text { Average }\end{array}$ & $\begin{array}{c}\text { per cent } \\
<3.0 \\
3.00 \text { to } 3.99 \\
4.00 \text { to } 4.99 \\
5.00 \text { to } 5.99 \\
6.00 \text { to } 6.99 \\
7.00 \text { to } 7.99 \\
>7.99\end{array}$ & $\begin{array}{c}\text { per cent } \\
2.14 \\
3.48 \\
4.50 \\
5.56 \\
6.47 \\
7.32 \\
9.09\end{array}$ & $\begin{array}{c}m m . \mathrm{H}_{2} \mathrm{O} \\
85.9 \\
121.5 \\
157.4 \\
220.6 \\
257.9 \\
316.0 \\
366.8\end{array}$ & $\begin{array}{l}40.1 \\
34.9 \\
34.9 \\
39.7 \\
39.8 \\
43.2 \\
40.4 \\
39.4\end{array}$ & $\begin{array}{l}1.44 \\
1.17 \\
1.46 \\
1.53 \\
1.51 \\
1.56 \\
0.90\end{array}$ \\
\hline
\end{tabular}

In spite of the curvature which is demonstrable in the dilution experiments, when all the $173 \mathrm{ob}-$ servations are examined in families (see Table III), the osmotic pressure per gram per cent protein, $\pi / \mathrm{P}$, proves to be approximately the same in all families, having an average value of 39.4 $\mathrm{mm}$. $\mathrm{H}_{2} \mathrm{O}$. Since $\mathrm{P}$ represents the sum of the two fractions, $A$ and $G$, which may have different osmotic effects, statistical deductions from total protein are open to objection. It is impossible to secure sera in which all combinations of $A$ and $G$ appear; sera with albumin greatly increased or globulin much reduced do not seem to exist. It follows that sera with high protein contain excessive proportions of globulin, while those with low protein are particularly deficient in albumin.

It is possible, however, to meet this difficulty in part by examining the effect of variations of albumin or globulin alone in selected data. In Table IV all observations in which $G$ lies between

\section{TABLE IV}

Relation of concentration of albumin, $A$, to osmotic pressure, $\pi$, when globulin is between 1.5 and 2.5 per cent

\begin{tabular}{|c|c|c|c|c|c|}
\hline $\begin{array}{l}\text { Number of } \\
\text { observations }\end{array}$ & $\underset{\mathbf{A}}{\text { Range of }}$ & $\underset{\text { A }}{\text { Average }}$ & $\underset{\mathbf{G}}{\text { Average }}$ & $\underset{\pi}{\text { Average }}$ & $\underset{\pi / A}{\text { Average }}$ \\
\hline $\begin{array}{l}18 \\
16 \\
41 \\
13\end{array}$ & $\begin{array}{c}\text { per cent } \\
<2.5 \\
2.5 \text { to } 3.49 \\
3.50 \text { to } 4.49 \\
>4.49\end{array}$ & \begin{tabular}{|c|} 
per cent \\
1.93 \\
3.07 \\
3.72 \\
4.85
\end{tabular} & $\begin{array}{c}\text { per cent } \\
1.97 \\
1.93 \\
1.89 \\
2.20\end{array}$ & \begin{tabular}{|c|}
$m m . H_{2} O$ \\
125.0 \\
187.7 \\
234.7 \\
326.5
\end{tabular} & $\begin{array}{l}64.8 \\
61.1 \\
63.1 \\
67.3\end{array}$ \\
\hline \multicolumn{2}{|c|}{ Average } & & & & 63.8 \\
\hline
\end{tabular}


1.5 and 2.5 per cent have been arranged in families of A. Altogether there were 88 such observations. Neither $G$ nor $\pi / A$ in this series varies systematically from family to family. The mean value of $\pi / \mathrm{A}$ is 63.8. This would seem to imply that $\pi$ becomes $\mathrm{O}$ when $\mathrm{A}=\mathrm{O}$, which could only mean that the osmotic pressure of total protein was a linear function of albumin alone and that the osmotic contribution of globulin was negligible. When all observations are plotted graphically as $\mathrm{A}=x, \pi=y$, the points take a roughly linear arrangement that appears to pass through or near the origin. There is, however, a distinct tendency for points representing sera with unusually high globulin to diverge from the alignment, an indication that globulin has a small, but perceptible osmotic effect.

So small does this effect appear to be that the correlation between $\pi$ and $G$ is hardly more than perceptible. Only when $\mathrm{G}$ is great can its effect be detected even when only observations with $A$ between 3.5 and 4.5 per cent are analyzed separately.

Since the curvature of the relation of $\mathrm{P}, \mathrm{G}$ and A to $\pi$ is sufficiently small, reasonably accurate prediction formulae might be secured by treating it as a straight line. With this in mined, formulae relating $\mathrm{P}, \mathrm{A}, \mathrm{G}$, and $\mathrm{A}+\mathrm{G}$, respectively to $\pi$ have been derived by regression equations. Since osmolar concentrations should, properly, be expressed in terms of weight of solute per weight of water, all concentrations of protein and its fractions were first corrected to grams of protein per kilo of water by means of the equation $W=98.40-0.718 \mathrm{P}$, mentioned above. It has already been stated that this treatment tended to reduce the curvature in the dilution experiments.

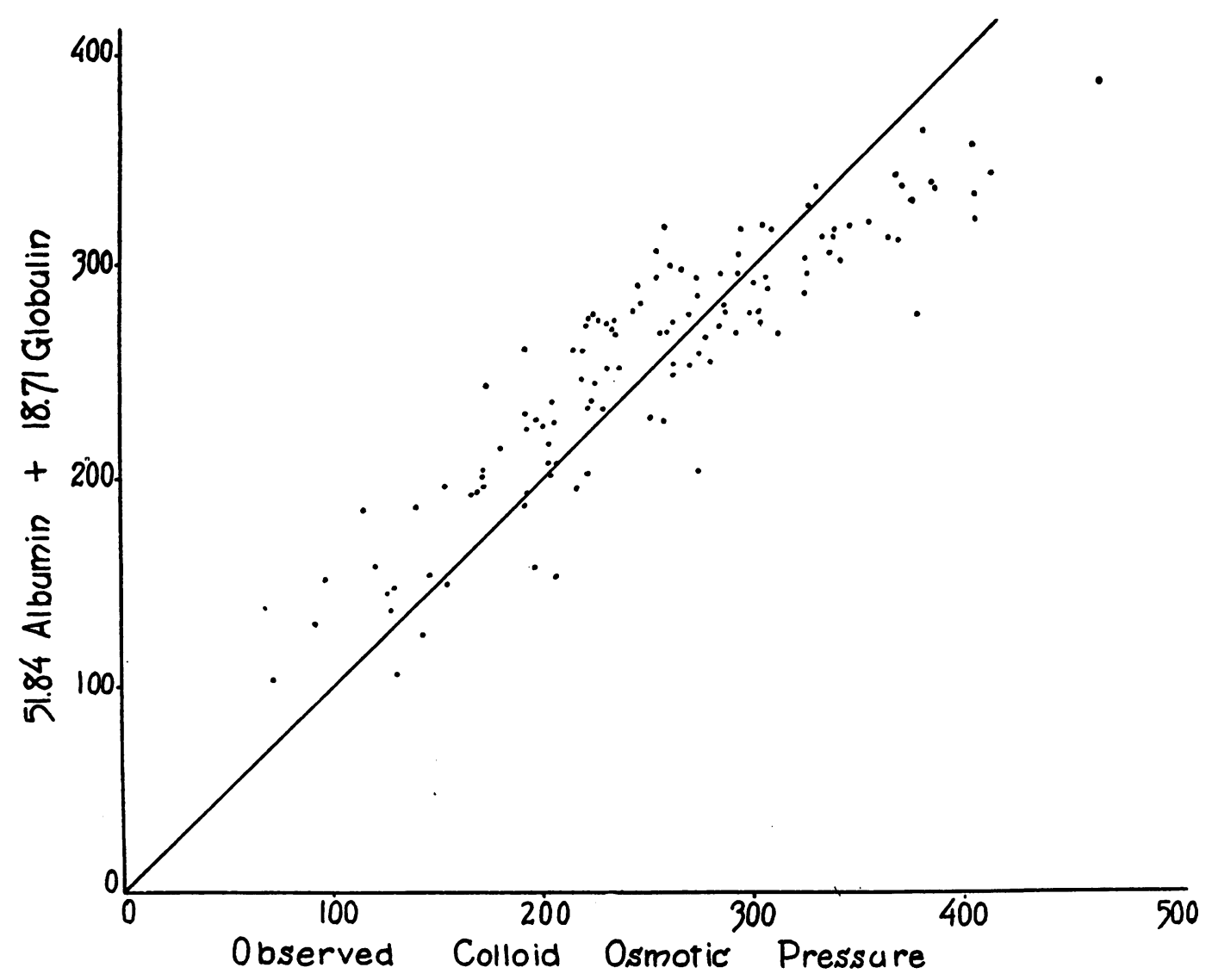

Fig. 2. Comparisons of Observed and Calculated Osmotic Pressures.

$A$ and $G$ are expressed in terms of grams per 100 grams of water in serum. 
The assumption was first made that all curves pass through the origin, i.e., that $\pi$ becomes $\mathrm{O}$ when protein does. With this assumption the following equations were derived. In all, protein concentrations are expressed as grams per kilo of water, osmotic pressure as $\mathrm{mm} . \mathrm{H}_{2} \mathrm{O}$. For these estimations, only the 121 measurements on native serum were used. The inclusion of the measurements from diluted sera yields slightly different coefficients, but the differences are not important.

$\begin{array}{lcr}\text { Equation } & \begin{array}{c}\text { Average } \\ \text { deviation }\end{array} & \begin{array}{r}\text { Standard } \\ \text { deviation }\end{array} \\ \text { 1. } \pi=37.8 \mathrm{P}_{w} & \pm 36.7 & \pm 45.7 \\ \text { 2. } \pi=64.1 \mathrm{~A}_{w} & \pm 31.1 & \pm 44.8 \\ \text { 3. } \pi=78.9 \mathrm{G}_{\omega} & \pm 90.0 & \\ \text { 4. } \pi=51.8 \mathrm{~A}_{w}+18.7 \mathrm{G}_{\diamond} & \pm 29.7 & \pm 35.5\end{array}$

It is obvious at once that the relation of $\pi$ to $G$ is extremely loose; the average deviation is greater than the coefficient. Formulae derived from $\mathrm{P}$ or from $\mathrm{A}$ alone are almost equally good, although the latter is to be preferred slightly, probably because in certain instances the total protein is composed chiefly of globulin, which has a lower osmotic pressure than albumin. The equation derived from $A$ and $G$ together conforms best to the data. The deviations from this equation are presented graphically in Figure 2. The points at the extreme right of the figure fall systematically below the line, while those at the extreme left fall predominantly above it. The points at the extreme right represent observations with unusually high protein composed predominantly of globulin.

It is hard to say to what extent the apparent curvature in the arrangement of the points is comparable to the curvature in the dilution experiments and how far it should be attributed to the combinations of protein fractions in the particular sera which were selected for analysis. The

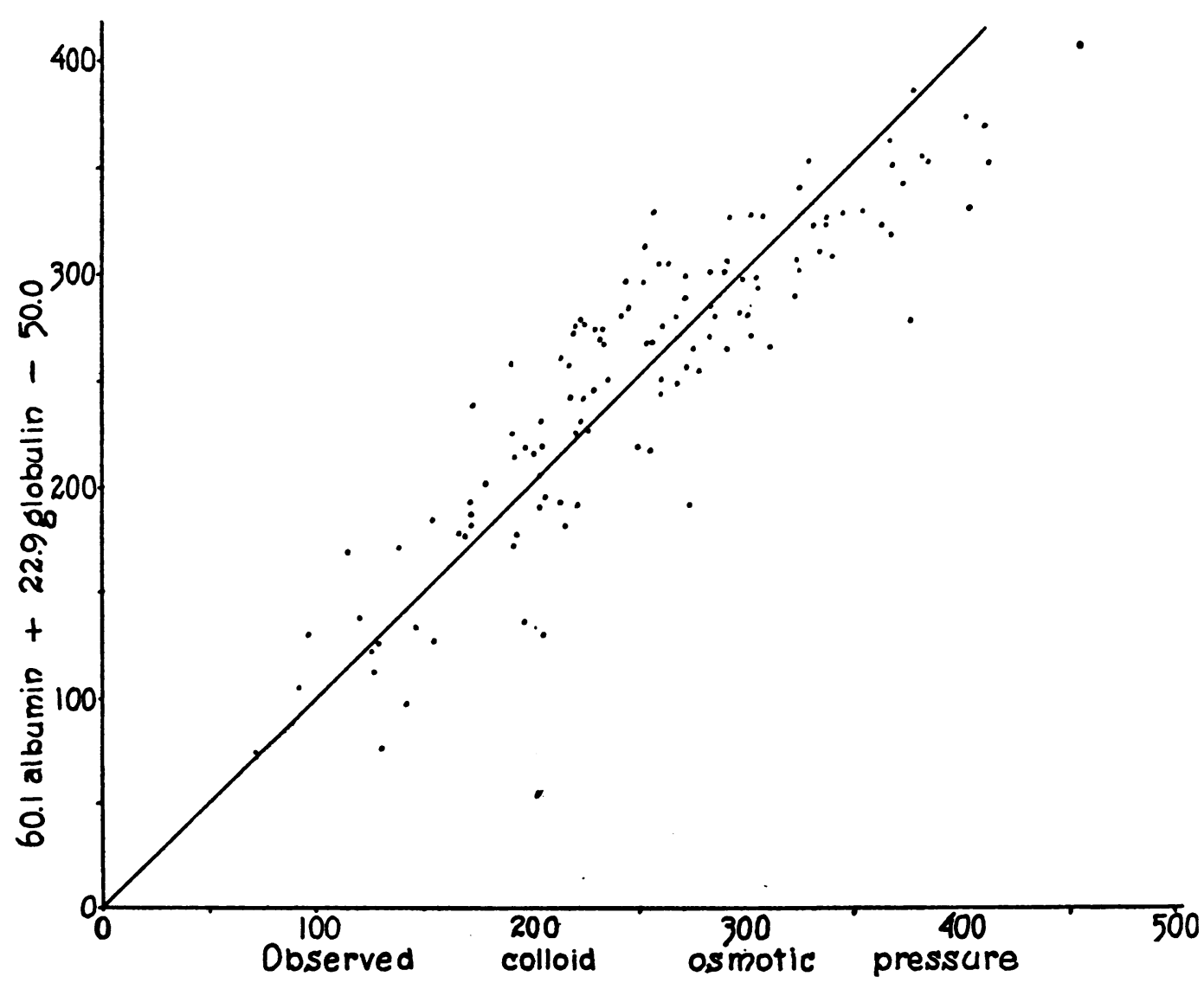

Fig. 3. Comparisons of Observed and Calculated Osmotic Pressures.

$A$ and $G$ are expressed in terms of grams per 100 grams of water in serum. 
range of variation of protein concentration could not have been made so large without purposeful selection of sera with abnormal $A / G$ ratios. Since a certain amount of uncorrected curvature may be expected on theoretical grounds, the assumption that the best straight line will pass through the origin is unwarranted. A better fit is obtained by the equation.

5. $\pi=60.9 \quad \mathrm{~A}_{w}+22.9 \quad \mathrm{G}_{w}-50.0 \quad$ A.D. $=$ \pm 27.6 . S.D. $= \pm 32.6$.

This is illustrated in Figure 3.

\section{DISCUSSION}

Beyond the statement that these measurements of total colloid osmotic pressure agree in general with those of other reliable investigators $(7,14$, $15,17,20,23,24)$, comparisons on the basis of magnitude alone can not be profitable, since small variations depend so largely on details of technical procedure. The method employed is believed, for reasons stated above, to be soundly devised, and yields reproducible measurements. The errors of measurement are unfortunately large; just how large it is hard to say. It is believed, however, that neither the differences between duplicates in Table I nor the variations of measurements of the osmotic pressure of standard acacia solutions give a correct estimate of the absolute error in actual analyses of sera. This impression is derived from the variability of the dilution curves and also from erratic changes of the protein osmotic pressure in repeated observations on individual subjects. In the majority of instances both the absolute magnitude of the osmotic pressure and the changes of pressure in such cases agree reasonably well with the protein concentrations. Occasionally, however, unaccountable departures from the common rule are encountered. For example, in Subject 19 the change of $\pi$ between the first 2 observations is altogether too large. It seems likely that the first measurement of $\pi$ was too small. Similarly, the second $\pi$ in Case 45 is out of line with the other 2, which are of the expected order of magnitude. Discrepancies of this kind noted by other observers have been attributed to variations in the osmotic properties of the serum proteins without sufficient consideration of the degree of error in measurement of osmotic pressure. Serum contains no known colloids other than protein which produce an appreciable osmotic pressure. Fishberg (18) has suggested that the lipoids of serum must be given consideration. Adair and Robinson (19), however, found that removal of lipoids had no effect on the osmotic pressure of the serum proteins. Several of the patients in the present study had lipemia, in one or two cases of an extreme degree. Nevertheless, the colloid osmotic pressure of their sera was not unexpectedly high (see, for example, Number 78).

The factors for the osmotic pressure of the separate components of serum, albumin and globulin, in Equation 4, approach the relative orders of magnitude derived by comparable methods by Govaerts (23) and by von Farkas (24). They are not proportional to the generally accepted molecular weights of albumin and globulin; the coefficient of $G$ is too small and that of albumin proportionately too large. This does not mean that the osmotic pressure of either of the components is necessarily different in serum than it is in pure solution. These equations were developed on a purely empirical basis to fit certain experimental data. Undoubtedly, it would be possible by mathematical juggling to devise a more complicated equation which would fit the data even better than the formulae which have been presented. No significance could be attached to the particular form taken by such an equation. Wells, Youmans and Miller (20) found that data from a series of determinations comparable to those here presented were best described by the equation, $\pi=\mathrm{P}(21.4+5.9 \mathrm{~A})$. As they have pointed out, this formula implies that the partial osmotic pressure of globulin depends upon the concentration of albumin in serum. The only evidence for such an interrelation is found in certain preliminary observations by McFarlane (25). Adair and Robinson (19), from similar experiments, concluded that the proteins in serum conformed to Dalton's law of partial pressures. The present measurements differ systematically from those of Wells, Youmans and Miller (20), probably because of certain differences of technical procedure. When allowance is made for this difference, there is still no evidence 
that globulin surrenders its individuality when it is combined with albumin in serum. With the variable curvature of $\pi / \mathrm{P}$ with $\mathrm{P}$, the relatively small osmotic pressure of $G$ and special characteristics of the particular sera selected for examination, ${ }^{8}$ it is idle to draw inferences concerning the specific osmotic properties of protein fractions from statistical treatment of measurements of osmotic pressure in whole serum.

Since the relation between $\pi$ and $P$ is curvilinear, the mean line which will best describe it should not pass through the origin. To this extent Equation 5 may be more accurate than 4. In the last analysis, the utility of prediction formulae developed statistically depends on the character of the data on which they are based. The observations here employed are fairly representative and as evenly distributed over a wide range of protein concentrations as clinical material permits. Unless practicable methods for the measurement of the colloid osmotic pressure of serum can be greatly improved in accuracy, estimations from prediction equations based on representative data secured by sound methods may be quite as reliable, for relative purposes, at least, as direct measurements.

\section{SUM MARY}

The relation of the concentration of serum protein, and its fractions albumin and globulin, to the colloid osmotic pressure of human serum has been reëxamined. Empirical equations have been derived for the estimation of colloid osmotic pressure from the concentrations of protein, albumin and globulin in the water. of serum.

The authors wish to express their grateful appreciation of aid received from Dr. Alexander Winkler in the statistical treatment of the data and from Dr. Michael J. Lepore who made some of the analyses for protein and measurements of osmotic pressure.

${ }^{3}$ There can be no certainty that the osmotic pressure of the globulin (presumably chiefly euglobulin) which makes up the bulk of the protein in myeloma and lymphogranuloma, the chief sources of hyperproteinemic sera, is the same as the osmotic pressure of normal serum globulin. Failure to include sera with high globulin would limit the practical utility of any prediction formula.

\section{BIBLIOGRAPHY}

1. Pierce, H. F., Nitrocellulose membranes of graded permeability. J. Biol. Chem., 1927, 75, 795.

2. Govaerts, P., Recherches cliniques sur la pression osmotique des colloìdes du sérum. I. Technique. Compt. rend. Soc. de biol., 1923, 89, 678.

3. Turner, A. H., The validity of determinations of the colloid osmotic pressure of serum. J. Biol. Chem., 1932, 96, 487.

4. Hitchcock, D. I., Protein films on collodion membranes. J. Gen. Physiol., 1925, 8, 61.

5. Smith, R. G., and Sternberger, H. R., Diffusible and non-diffusible blood serum calcium following intravenous injections of calcium salts. J. Biol. Chem., 1932, 96, 245.

6. Hitchcock, D. I., Personal communication to C. H.W.

7. Krogh, A., and Nakazawa, F., Beiträge zur Messung des kolloid-osmotischen Druckes in biologischen Flüssigkeiten. Biochem. Ztschr., 1927, 188, 241.

8. Hill, R. M., The determination of colloid osmotic pressures in small quantities of fluid. J. Biol. Chem., 1933, 99, 323.

9. Moore, B., and Roaf, H. E., Direct measurements of the osmotic pressure of solutions of certain colloids. Biochem. J., 1907, 2, 34.

10. Cox, H. R., and Hyde, R. R., Physical factors involved in ultrafiltration. Am. J. Hyg., 1932, 16, 667.

11. Yanagi, K., A clinical and experimental study of the stability of colloid osmotic pressure of serum protein. J. Clin. Invest., 1935, 14, 853.

12. Howe, P. E., The determination of proteins in blood -a micro-method. J. Biol. Chem., 1921, 49, 109.

13. Austin, J. H., Cullen, G. E., Hastings, A. B., McLean, F. C., Peters, J. P., and Van Slyke, D. D., Studies of gas and electrolyte equilibria in blood. I. Technique for collection and analysis of blood, and for its saturation with gas mixtures of known composition. J. Biol. Chem., 1922, 54, 121.

14. Verney, E. B., The osmotic pressure of the proteins of human serum and plasma. J. Physiol., 1926, 61, 319.

15. Mayrs, E. B., The functional pathology of nephritis. Quart. J. Med., 1926, 19, 273.

16. Marrack, J., and Hewitt, L. F., The effect of hydrogen ion concentration and protein concentration on the osmotic pressure of serum-proteins. Biochem. J., 1927, 21, 1129.

17. Cope, C. L., The osmotic pressure of the blood proteins in nephritis. Quart. J. Med., 1928, 22, 91.

18. Fishberg, E. H., The relations of the serum proteins and lipids to the osmotic pressure. J. Biol. Chem., 1929, 81, 205.

19. Adair, G. S., and Robinson, M. E., The analysis of the osmotic pressures of the serum proteins and the molecular weights of albumins and globulins. Biochem. J., 1930, 24, 1864.

20. Wells, H. S., Youmans, J. B., and Miller, D. G., Jr., A formula and nomogram for the estimation of 
the osmotic pressure of colloids from the albumin and total protein concentrations of human blood sera. J. Clin. Invest., 1933, 12, 1103.

21. Grönwall, A., Uber die Bedeutung des Verhältnisses zwischen Bluteiweisskonzentration und dem sogenannten kolloidosmotischen Druck. Biochem. Ztschr., 1935, 276, 223.

22. Eisenman, A. J., Mackenzie, L. B., and Peters, J. P., Protein and water of serum and cells of human blood. J. Biol. Chem., 1936, 116, 33.
23. Govaerts, $P$., Influence de la teneur du sérum en albumines et en globulines sur la pression osmotique des protéines et sur la formation des oedèmes. Bull. Acad. roy. de méd. de Belgique, 1927, 7, 356.

24. Farkas, G. v., Zum Problem der Berechnung des kolloidosmotischen Druckes der Bluteiweisskörper. Ztschr. f. d. ges. exper. Med., 1935, 97, 18.

25. McFarlane, A. S., The ultracentrifugal protein sedimentation diagram of normal human, cow and horse serum. Biochem. J., 1935, 29, 660. 